\title{
Reduction in the antibacterial effect of oxytetracycline in sea water by complex formation with magnesium and calcium
}

\author{
Bjørn T. Lunestad, Jostein Goksøyr \\ Department of Microbiology and Plant Physiology,University of Bergen, Jahnebakken 5, N-5007 Bergen, Norway
}

\begin{abstract}
Oxytetracycline (OT) is used extensively in the treatment of bacterial diseases in marine fish. The standard dose recommended for treatment of fish is 5 to 10 times higher than doses commonly used in medical practice, indicating that OT is poorly absorbed. This is especially true for fish held in sea water, where the intestinal uptake is substantially reduced as compared to fish in fresh water. OT forms complexes with magnesium and calcium. We have determined the complex constants and calculated that when therapeutic concentrations of OT are present in sea water, only about $5 \%$ of the OT exists in the free form. Of the bound OT, the 1:1 OT-magnesium complex predominates. The complex formation in sea water results in a strong reduction in the antibacterial effect of OT This has been demonstrated in vitro. The poor intestinal uptake and reduced antibacterial effect of complex-bound OT is caused by an alteration of the molecular charge that diminishes its ability to cross lipid-rich biological membranes. A major portion of the OT administered to farmed salmonids inevitably ends up in the environment, especially in the sediments under aquaculture facilities. No mechanism is known for biodegradation of OT and thus it can remain in the sediments long enough to affect the indigenous bacterial flora and induce resistance. For these reasons the use of OT in marine environments should be questioned.
\end{abstract}

\section{INTRODUCTION}

In the treatment of bacterial diseases in marine fish, oxytetracycline (OT) has often been the agent of choice. Even though a reduction in the use of OT has been observed in recent years, considerable amounts are still prescribed. In 1988 the amount of OT used in Norwegian aquaculture was $18200 \mathrm{~kg}$, measured as the active component. The corresponding value for 1989 was $5000 \mathrm{~kg}$.

Tetracyclines have a number of potential metal binding sites (Gulbis \& Everett 1976, Day et al. 1978, Lambs et al. 1984). The ability of tetracyclines to form complexes with di- and trivalent cations has long been known (Albert 1953, Albert \& Rees 1956, Clive 1968). This ability is most strongly pronounced for hydrophilic tetracyclines (mainly tetracycline and oxytetracycline). Lipophilic tetracycline derivatives, such as doxycycline and minocycline do not exhibit the same ability to form complexes (Goodman \& Gilman 1985). The presence of di- or trivalent cations has also been shown to mediate the binding of tetracyclines to macromolecules (Kohn 1961)

(c) Inter-Research/Printed in F. R. Germany
Sea water with a salinity of $35 \%$ contains $54 \mathrm{mM}$ $\mathrm{Mg}^{2+}$ and $10 \mathrm{mM} \mathrm{Ca}^{2+}$ (Potts \& Parry 1964). The concentration of other di- or trivalent cations is negligible in sea water. In this study, we show, using in vitro tests, how complex-formation with $\mathrm{Mg}^{2+}$ and $\mathrm{Ca}^{2+}$ affects the antibacterial activity of OT.

\section{MATERIAL AND METHODS}

The complex constants for OT-hydrochloride (Sigma Chemical Company, USA) with magnesium and calcium were determined spectrophotometrically (Shimadzu UV-240 spectrophotometer). OT was added to buffered solutions containing magnesium or calcium at concentrations similar to those found in sea water. The OT was added to yield concentrations commonly used for minimum inhibitory concentration (MIC) testing (2 to $100 \mu \mathrm{M}$; Mwt 496.9). The large excess of bivalent cation used ensured that the complex formed was mainly $1: 1$. Because the ability to form complexes is $\mathrm{pH}$ dependent, all measurements were done in a 12.5 $\mathrm{mM}$ borate/ $\mathrm{HCl}$ buffer solution, $\mathrm{pH} 8$ (Dawson et al. 
1969). The ionic strength was adjusted to that of sea water using $\mathrm{NaCl}$. Investigations carried out by White \& Pearce (1982) on chlorotetracycline (aureomycine) revealed a maximum complex binding at $\mathrm{pH}$. At this $\mathrm{pH}, 1: 1$ complexes are formed.

A freshly prepared stock solution of $1 \mathrm{mM}$ OT in borate $/ \mathrm{HCl}$ buffer was diluted to appropriate concentrations with the same buffer. Absorption spectra were recorded to give the spectrum of OT alone. Then $\mathrm{CaCl}_{2}$ or $\mathrm{MgSO}_{4}$ was added until no further change in the absorption spectrum was observed. Under these conditions, OT exists predominantly as a $1: 1$ complex with the added cation. When the absorption characteristics of free and complex-bound OT had been determined, their specific contribution to the total absorption at a given wavelength could be obtained. Thus the complex constant could be calculated from the concentrations of free OT, complex-bound OT and the cation in accordance with the equation:

$$
\mathrm{K}=\frac{\mathrm{CMeOT}}{\mathrm{CMe} \cdot \mathrm{C} \mathrm{OT}}
$$

$\mathrm{C}$ MeOT is the concentration of metal-OT complex, $\mathrm{C}$ Me the concentration of free metal, $\mathrm{C} O \mathrm{OT}$ the concentration of free OT and $\mathrm{K}$ the complex constant. The initially added OT equals $\mathrm{C}$ MeOT $+\mathrm{C} \mathrm{OT}$, and the added metal equals $\mathrm{C} \mathrm{MeOT}+\mathrm{C} \mathrm{Me}$.

Bacterial sensitivity to OT was determined using the MIC method and the disc-diffusion test. In all tests the medium used was Tryptone Soya Agar (TSA) which is recommended by the producer, Oxoid, for sensitivity testing. The medium was prepared with Trypton Soya Broth, Oxoid (20 $\mathrm{g} \mathrm{I}^{-1}$ ) and Special Agar Noble, Difco $\left(15 \mathrm{~g} \mathrm{l}^{-1}\right)$ the $\mathrm{pH}$ being adjusted to 8 with borate buffer. The agar was supplemented with either $25 \% \mathrm{NaCl}$, $70 \%$ seawater, $10 \mathrm{mM} \mathrm{Ca}^{2+}\left(\right.$ as $\left.\mathrm{CaCl}_{2}\right), 10 \mathrm{mM} \mathrm{Mg}^{2+}$ or

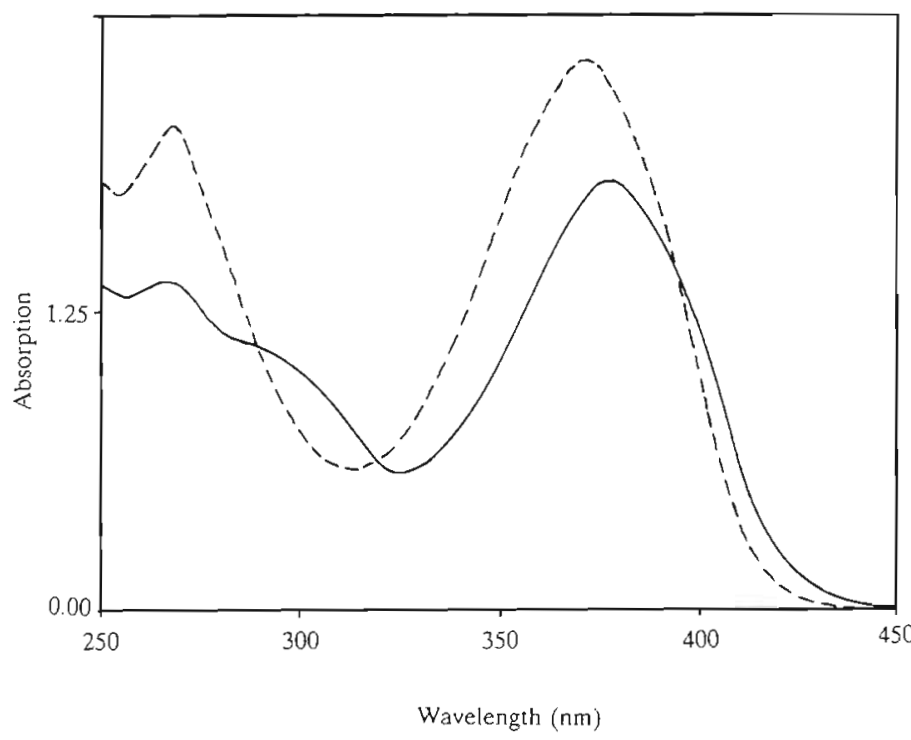

$54 \mathrm{mM} \mathrm{Mg}^{2+}$ (as $\mathrm{MgCl}_{2}$ ). In all cases the ionic strength was adjusted to a level equal to $25 \% \mathrm{NaCl}$. For MIC evaluation the strains were plated on TSA containing doubling concentrations of OT in the range 1 to $256 \mu \mathrm{M}$ $\left(0.5\right.$ to $\left.128 \mu \mathrm{g} \mathrm{mi}^{-1}\right)$. For disc-diffusion tests, a thin lawn of bacteria was spread over the agar surface with a cotton swab as recommended by the disc producer (Oxoid). Discs containing $30 \mu \mathrm{g}$ OT were placed on the lawn of bacteria before incubation. Inhibition zones were measured as the distance from the edge of the disc to the border of uninhibited bacterial growth.

The antibacterial effect of OT was investigated on 3 well described bacterial strains Escherichia coli JM103, E. coli B6 and Yersinia ruckeri RS $11^{\mathrm{T}}$ (ATCC 29473). Y. ruckeri RS $11^{\mathrm{T}}$ has been shown to grow on media contaning $6 \% \mathrm{NaCl}$ (G. H. Hansen, this department, pers. comm.) $Y$. ruckeri has been shown able to infect fish held in sea water (Sparboe et al. 1986)

When medicating diseased fish, the therapeutic agent is usually coated on food pellets. A major part of the OT given in this way ends up in the environment, either directly as a result of wasteful over-feeding or indirectly via the faeces. Particle-bound OT will, provided the water current is moderate, settle in the vicinity of the aquaculture facility. The sediment will thus receive considerable amounts of OT. To examine the antibacterial effect of complex-bound OT on sediment bacteria we included 5 randomly chosen strains isolated from sediments under marine aquaculture facilities in our investigations. These bacteria were Gram-negative, motile, oxidase-positive, rods. For the antibiotic sensitivity tests, the 2 strains of Escherichia coli, were incubated for 24 h at $30^{\circ} \mathrm{C}$, Yersinia ruckeri was incubated for $48 \mathrm{~h}$ at $22^{\circ} \mathrm{C}$, and the 5 strains of sediment bacteria were incubated for $72 \mathrm{~h}$ at $15^{\circ} \mathrm{C}$. The results were read following these incubation times.
Fig. 1. Absorption spectra of $100 \mu \mathrm{M}$ OT in borate $/ \mathrm{HCl}$ buffer solutions ( $\mathrm{pH}$ 8) of $54 \mathrm{mM} \mathrm{Mg}^{2+}(---)$ or $10 \mathrm{mM}$ $\mathrm{Ca}^{2+}(-)$. The ionic strength was adjusted to the sea water level with $\mathrm{NaCl}$ 
Fig. 2. Absorption spectra of $100 \mu \mathrm{M}$ OT in sea water $\mathrm{pH} 8$ $(---)$, borate/ $\mathrm{HCl}$ buffer $\mathrm{pH} 8(-\cdot)$ and distilled water $\mathrm{pH} 7$ (-). The ionic strength in the buffer and distilled water was adjusted to sea water level with $\mathrm{NaCl}$

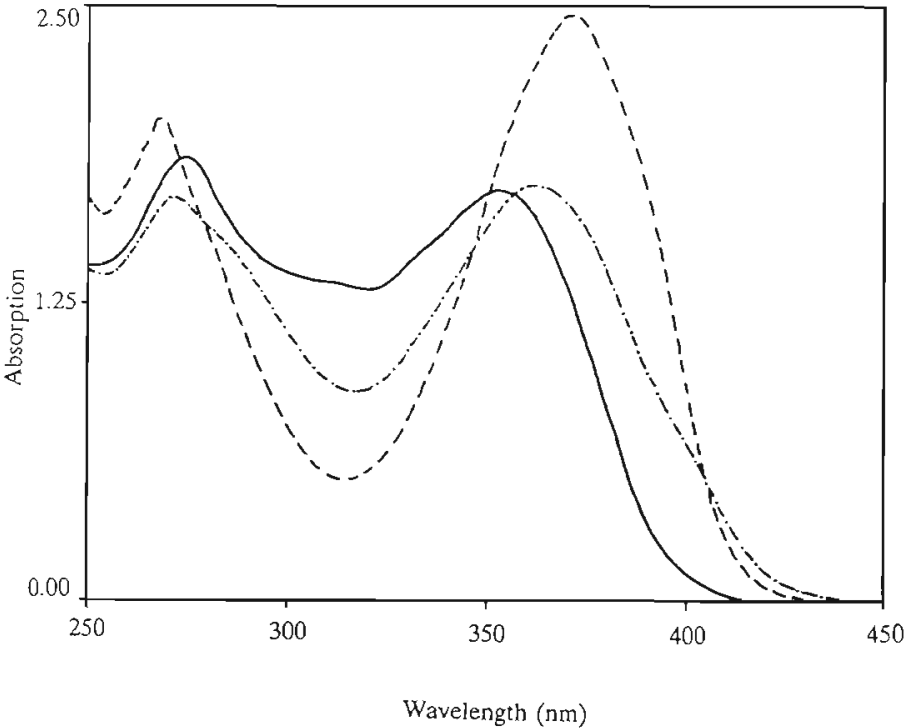

the absorption values at $390 \mathrm{~nm}$, where the highest difference in absorption between free and complexbound OT was observed. The absorption of OT complexes was found using a cation concentration of $0.1 \mathrm{M}$. There was no increase in the absorption when increasing the concentration of the cation above $0.1 \mathrm{M}$, indicating that the complex-binding was close to $100 \%$. Molar absorption values were found to be $10000 \mathrm{~cm}^{-1}$ for free OT, $13200 \mathrm{~cm}^{-1}$ for MgOT, and $16500 \mathrm{~cm}^{-1}$ for $\mathrm{CaOT}$. The values used for calculating the complex constants are listed in Table 1 . The constants were found to be $2.9 \times 10^{2} \mathrm{M}^{-1}$ for $\mathrm{MgOT}$ and $1.9 \times 10^{2} \mathrm{M}^{-1}$ for CaOT, indicating that $\mathrm{Mg}^{2+}$ is the most avid ligand. The complex constants given above are the mean of the values from Table 1 .

The addition of magnesium or calcium to the medium led to a strong reduction in the antibacterial activity of

Table 1. Determination of complex constants for MgOT and CaOT, and calculation of free OT in $35 \%$ sea water when present in therapeutic concentrations $\left(0.5\right.$ to $100 \mu \mathrm{g} \mathrm{ml}^{-1}$ ). The complex constants have been determined in $35 \% \mathrm{NaCl}$ (to give the same ionic strength as in sea water), buffered to $\mathrm{pH} 8.0$ with $12.5 \mathrm{mM}$ borate buffer. Molar absorption at $390 \mathrm{~nm} \mathrm{was} 10000 \mathrm{~cm}^{-1}$ for OT, $16500 \mathrm{~cm}^{-1}$ for $\mathrm{CaOT}$ and $13200 \mathrm{~cm}^{-1}$ for $\mathrm{MgOT}$

\begin{tabular}{|c|c|c|c|c|}
\hline Cation conc. & OT conc. & $A_{390}$ & $\mathrm{~K}$ & Free OT \\
\hline \multicolumn{5}{|l|}{$\mathrm{Mg}^{2+}$} \\
\hline $10^{-2} \mathrm{M}$ & $5 \times 10^{-5}(\mathrm{M})$ & 0.62 & 300 & $1.25 \times 10^{-5}(\mathrm{M})$ \\
\hline $10^{-2} \mathrm{M}$ & $10 \times 10^{-5}(\mathrm{M})$ & 1.23 & 285 & $2.50 \times 10^{-5}(\mathrm{M})$ \\
\hline \multicolumn{5}{|l|}{$\mathrm{Ca}^{2+}$} \\
\hline $10^{-2} \mathrm{M}$ & $5 \times 10^{-5}(\mathrm{M})$ & 0.71 & 185 & $1.75 \times 10^{-5}(\mathrm{M})$ \\
\hline $10^{-2} \mathrm{M}$ & $10 \times 10^{-5}(\mathrm{M})$ & 1.43 & 195 & $3.38 \times 10^{-5}(\mathrm{M})$ \\
\hline \multirow{5}{*}{$\begin{array}{l}\text { Sea water } \\
\left(54 \mathrm{mM} \mathrm{Mg}^{2+},\right. \\
\left.10 \mathrm{mM} \mathrm{Ca}^{2+}\right)\end{array}$} & & & & \\
\hline & $0.5\left(\mu \mathrm{g} \mathrm{ml}^{-1}\right)$ & & Calculated & $0.027\left(\mu \mathrm{g} \mathrm{ml}^{-1}\right)$ \\
\hline & $5.0\left(\mu \mathrm{g} \mathrm{ml} l^{-1}\right)$ & & Calculated & $0.27\left(\mu \mathrm{g} \mathrm{ml}^{-1}\right)$ \\
\hline & $50 \quad\left(\mu \mathrm{g} \mathrm{ml}^{-1}\right)$ & & Calculated & $2.7 \quad\left(\mu \mathrm{g} \mathrm{ml}^{-1}\right)$ \\
\hline & $100 \quad\left(\mu g \mathrm{ml}^{-1}\right)$ & & Calculated & $\left(\mu \mathrm{g} \mathrm{m} l^{-1}\right)$ \\
\hline
\end{tabular}


Table 2. The separate contributions of $\mathrm{Mg}^{2+}$ and $\mathrm{Ca}^{2+}$ in reducing the antibacterial effect of OT expressed as inhibition zone sizes on TSA. Inhibition zones obtained when using discs containing $30 \mu \mathrm{g}$ OT are given as the distance in mm from the edge of the disc to the border of uninibited bacterial growth. V.257, V.369, E.112, E.177 and E.189 are Gram-negative, oxidase-positive, motile rods isolated from a marine aquaculture sediment. They are included as representatives for bacteria in the environment

\begin{tabular}{lcccc}
\hline Strain & $25 \% \mathrm{NaCl}$ & $10 \mathrm{mM} \mathrm{Ca}{ }^{2+}$ & $10 \mathrm{mM} \mathrm{Mg}^{2+}$ & $54 \mathrm{mM} \mathrm{Mg}^{2+}$ \\
\hline Escherichia coli B6 & 11.0 & 9.0 & 7.0 & 3.0 \\
E. coli JM-103 & 8.5 & 7.0 & 5.0 & 0.0 \\
Yersinia ruckeri RS-11 ${ }^{\mathrm{T}}$ & 10.5 & 8.0 & 5.5 & 0.0 \\
V.257 & 2.0 & 1.5 & 1.0 & 0.0 \\
V.369 & 13.0 & 6.0 & 5.0 & 3.0 \\
E.112 & 12.0 & 5.5 & 4.0 & 1.5 \\
E.177 & 15.5 & 5.0 & 3.5 & 0.0 \\
E.189 & 13.0 & 9.5 & 8.5 & 5.5 \\
\hline
\end{tabular}

OT as shown in Tabie 2. In equimolar concentrations, $\mathrm{Mg}^{2+}$ exhibited a greater ability than $\mathrm{Ca}^{2+}$ at reducing the effect of OT. This was in agreement with the complex constants previously determined

In Figs. 3 and 4 the size of the inhibition zones obtained on TSA with antibiotic discs were plotted against the amount of sea water added to the medium. For all strains, the sizes of the inhibition zones were reduced by more than $55 \%$ when tested on TSA prepared with $100 \%$ sea water as compared to TSA prepared with $35 \% \mathrm{NaCl}$ in $\mathrm{pH}$-adjusted distilled water (pH 8).

MIC tests were carried out with $70 \%$ sea water or with varying concentrations of $\mathrm{Mg}^{2+}$ or $\mathrm{Ca}^{2+}$. The results are listed in Table 3 . In all cases, addition of $\mathrm{Mg}^{2+} / \mathrm{Ca}^{2+}$ as sea water or as chemicals led to a profound increase in the ability of the bacteria to tolerate

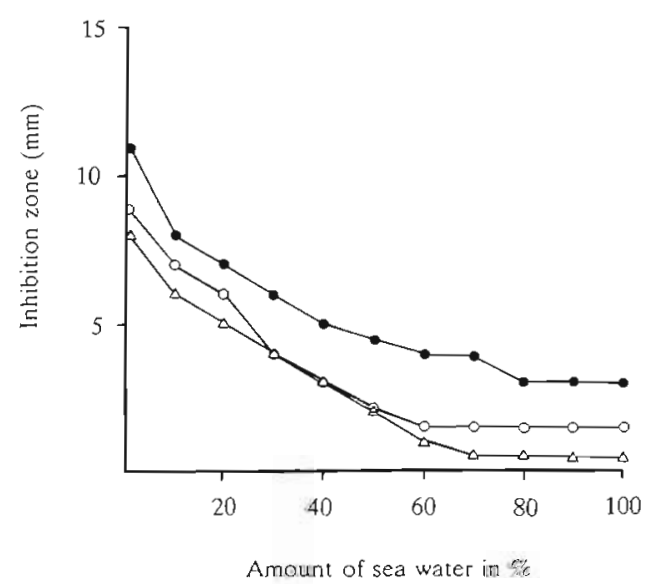

Fig. 3. Inhibition zones (mm) for Escherichia coli JM-103 (-). E. coli B6 (•) and Yersinia ruckeri RS $11^{\mathrm{T}}$ (A.TCC 29473) (o) tested by agar diffusion using discs containing $30 \mu \mathrm{g}$ oxytetracycline. Inhibition zones where plotted against the amount of sea water added to Tryptone Soya Agar. Salinity was adjusted to $35 \%$ with $\mathrm{NaCl}$ and the $\mathrm{pH}$ to 8 . Inhibition zones were measured as the distance from the edge of the disc to the border of uninhibited bacterial growth
OT. The effect of $\mathrm{Mg}^{2+}$ was greater than the effect of $\mathrm{Ca}^{2+}$ as reported above.

To eliminate the possibility that the reduction in antibacterial effect was due to a reduced diffusion rate of OT complexes in the agar, experiments were also carried out in liquid media with agitation. The results confirmed the findings obtained using agar media (data not shown).

\section{DISCUSSION}

Because the effect of some antibacterial agents is influenced by cations in sea water, media used for testing antibiotic resistance of marine bacteria should

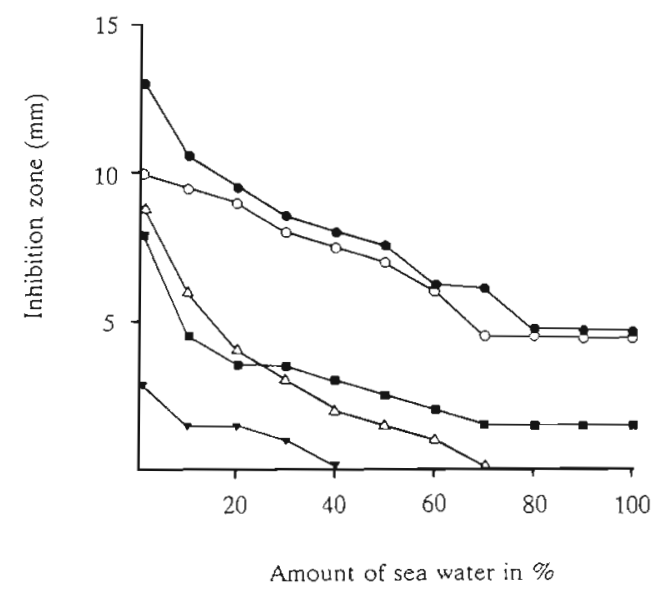

Fig. 4. Inhibition zones (mm) for 5 randomly chosen strains of sediment bacteria isolated from under aquaculture facilities The strains were not identified but were all Gram-negative, oxidase-positive, motile rods. Strains V.257 (v), V.369 (:)

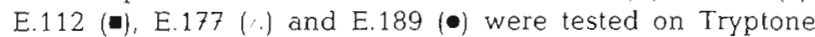
Soya Agar (TSA) using discs containing $30 \mu \mathrm{g}$ oxytetracycline. The inhibition zones are plotted against the amount of sea water added to the agar. The salinity was adjusted to $35 \%$ with $\mathrm{NaCl}$ and the $\mathrm{pH}$ to 8 . The inhibition zone were measured as the distance in $\mathrm{mm}$ from the edge of the disc to the border of uninhibited bacterial growth 
Table 3. Minimum inhibitory concentration (MIC) on TSA media containing various concentrations of seawater, $\mathrm{Mg}^{2+}$ or $\mathrm{Ca}^{2+}$ The MIC values are given as $\mu \mathrm{g}$ OT $\mathrm{ml}^{-1}$

\begin{tabular}{|c|c|c|c|c|c|}
\hline Strain & $25 \% \mathrm{NaCl}$ & $70 \%$ sea water & $10 \mathrm{mM} \mathrm{Ca}^{2+}$ & $10 \mathrm{mM} \mathrm{Mg}^{2+}$ & $54 \mathrm{mM} \mathrm{Mg}^{2+}$ \\
\hline Escherichia coli B6 & 0.5 & 4 & 1 & 4 & 32 \\
\hline E. coli JM-103 & 2 & 16 & 4 & 16 & 64 \\
\hline Yersinia ruckeri RS- $11^{\top}$ & 1 & 32 & 1 & 4 & 32 \\
\hline V.257 & 32 & $>128$ & 32 & $>64$ & $>64$ \\
\hline V.369 & 0.5 & 4 & 0.5 & 4 & 16 \\
\hline E. 112 & 0.5 & 2 & 4 & 16 & $>64$ \\
\hline E. 177 & 4 & 16 & 2 & 16 & 8 \\
\hline E.189 & 0.5 & 2 & 0.5 & 1 & \\
\hline
\end{tabular}

be prepared with natural or synthetic sea water containing $\mathrm{Mg}^{2+}$ and $\mathrm{Ca}^{2+}$. This will give a more correct picture of the actual antibacterial activity. We therefore recommend that an addition of $70 \%$ natural sea water or an equivalent amount of synthetic sea water should be set as a standard. The amount of $\mathrm{Mg}^{2+}$ and $\mathrm{Ca}^{2+}$ in commercial synthetic sea waters is approximately the same as found in natural sea water. Thus, 'Rila Marine' (Rila Products, Teaneck, NJ USA) contains $51.8 \mathrm{mM}$ $\mathrm{Mg}^{2+}$ and $12.2 \mathrm{mM} \mathrm{Ca}^{2+}$; 'Instant Ocean' (Aqarium Systems, Ohio, USA) contains $54.6 \mathrm{mM} \mathrm{Mg}^{2+}$ and 9.7 mM Ca ${ }^{2+}$; and 'Ultra Marine' (Waterlife Research Industries Ltd., UK) contains $53.3 \mathrm{mM} \mathrm{Mg}^{2+}$ and 10.0 $\mathrm{mM} \mathrm{Ca}^{2+}$ when diluted with distilled water as recommended by the producers.

A considerable underestimation of the level of OT resistance may occur when media prepared without sea water are used. In sea water, a calculated $95 \%$ of the OT, added at concentrations of from 0.5 to $100 \mu \mathrm{g}$ $\mathrm{ml}^{-1}$, is bound by the magnesium and calcium ions present in the water (Table 1). This binding is associated with a substantial loss in the antibacterial activity of OT, making it necessary to use considerably more OT to obtain the same effect as that obtained in the absence of these ions. This effect is clearly shown in Table 3 where the presence of $70 \%$ sea water in the MIC test medium increased the MIC values for the various organisms tested by an average of almost 10 fold (range 4 to 32 -fold) over those obtained on the medium containing $\mathrm{NaCl}$ in place of sea water. The $10-$ fold decrease in the efficiency of OT detected with sea water using the MIC assay does not quite equal the 20 fold decrease predicted by the spectral data in Table 1 , perhaps because of the imprecision built into the MIC assay method. Notwithstanding this, it is clear that the sensitivity of micro-organisms to OT in sea water will have to be determined on media containing calcium and magnesium ions if realistic estimates of their OT sensitivity are to be obtained.

Clinical reports have shown a clear reduction in gastrointestinal uptake of OT when administered orally with simultaneous intake of food containing di- or trivalent cations (Neuvonen 1976, Cunha et al. 1982). When seawater fish are medicated, OT will unavoidably come in contact with $\mathrm{Mg}^{2+}$ and $\mathrm{Ca}^{2+}$. This occurs when the OT-coated food pellet is in the sea water or in the gastrointestinal tract. Marine teleosts are hypoosmotic and must drink sea water to compensate for loss of water. Rainbow trout Salmo gairdneri kept in sea water have been reported to drink $129 \mathrm{ml} \mathrm{kg}^{-1} \mathrm{~d}^{-1}$. while rainbow trout kept in fresh water drink little or not at all (Usher et al. 1988). Drinking rate was independent of gut food content but was significantly higher in feeding fish (Usher et al. 1988). Thus, under sea water conditions the gut fluid can be regarded as slightly modified sea water. Because OT in the intestine must be taken up from the liquid phase, the presence of $\mathrm{Mg}^{2+}$ and $\mathrm{Ca}^{2+}$ will affect the absorption. This has lately been confirmed by Ellingsen et al. (unpubl.). Two groups of rainbow trout from the same cohort where medicated, using a standard OT regime, while kept in fresh or sea water. On the average, the tissue level of OT in the sea water group was approximately $30 \%$ of that found in the fresh water group.

To cross a biological lipid membrane, a drug must be undissociated (i.e. uncharged) and not bound to macromolecules (Goodman \& Gilman 1985). The reduced effect of complex-bound OT could be explained by the change in molecular charge when it combines with cations. Jun \& Lee (1980) have investigated the uptake of tetracycline in red blood cells. A reduction in the uptake was observed when red blood cells were kept in $0.9 \% \mathrm{NaCl}$ containing $2.5 \times 10^{-5} \mathrm{M} \mathrm{Ca}^{2+}$. When using the same concentration of $\mathrm{Ca}^{2+}$ and $\mathrm{NaCl}$ but adding $4 \%$ serum albumin, the uptake was significantly lower than in solutions containing $\mathrm{Ca}^{2+}$ or albumin alone. Thus cations probably mediate the binding of tetracyclines to macromolecules by serving as a connecting bridge (Kohn 1961).

Recent studies on tetracycline distribution in blood plasma have revealed that $\mathrm{Mg}^{2+}$ and $\mathrm{Ca}^{2+}$ complexes have a reduced ability to diffuse through erythrocyte 
membranes (Lambs et al. 1988). This effect was also due to alterations in molecular charge and thus the degree of lipid solubility

Because the major part of the OT administered to diseased fish reaches the environment, attention should be paid to the fate and effects of OT in the environment. Samuelsen et al. (1988) found in mesocosm experiments a rather rapid decrease in the OT concentration in the sediment during the first days after medication, but a residue of about $100 \mu \mathrm{M}$, or approximately $10 \%$ of the initial concentration, was observed over a long period (225 d). The lost OT was probably not degraded, but washed out from the sediment.

Bacterial resistance to tetracyclines is commonly observed. Tetracycline resistance determinants are the most widespread determinants among all bacterial species (Levy 1984). Despite the presence of a variety of tetracycline-resistant bacteria, no biodegradation pathways for OT are known. No significant loss of antibacterial activity was found when faecal material from animals treated with OT was stored isolated or in contact with soil over a period of months (Levy 1988). The main degradation mechanism for OT in the environment seems to be photodecomposition (Oka et al. 1989).

In view of the widespread observations of OT resistance, the persistent nature of OT, and the reduced uptake of $\mathrm{Mg}$-OT and $\mathrm{Ca}$-OT complexes in fish, the use of this antibiotic in marine environments should be questioned.

Acknowledgement. This work was supported by funds provided by The Norwegian Research Council for Fisheries Science, project no, V 701.231.

\section{LITERATURE CITED}

Albert, A. (1953). Avidity of terramycin and aureomycin for metallic cations. Nature, Lond. 172: 201

Albert, A., Rees, C. W (1956). Avidity of the tetracyclines for the cations of metals. Nature, Lond. 177. 433-434

Clive, D. L. J. (1968). Chemistry of tetracyclines. Q. Rev Chem. Soc. 22: 435-456

Cunha, B. A., Sibley, C. M., Ristuccia, A. M. (1982). Doxycycline. Rev. Theor drug Monit. 4: 115-135

Dawson, R. M. C., Elliott, D. C., Elliott, W. H., Jones, K. M. (1969). Data for biochemical research. Oxford University Press, Ely House, London

Responsible Subject Editor: Dr T. Evelyn, Nanaimo, B.C., Canada
Day, S. T., Crouthamel, W. G., Martinelli, L. C., Ma, J. K. H (1978). Mechanism of fuorometric analysis of tetracycline involving metal complexation. J. Pharm. Sci. 67. $1518-1523$

Goodman, L. S., Gilman, A. G. (1985). The pharmacological basis of therapeutics. Macmillan publishing company, New York

Gulbis, J., Everett, G. W. (1976). Metal binding characteristics of tetracycline derivatives in DMSO solution. Tetrahedron 32: $913-917$

Jun, H. W., Lee, B. H. (1980). Distribution of tetracycline in red blood cells. J. Pharm. Sci. 69: 455-457

Kohn, K. W. (1961). Mediation of divalent metal ions in the binding of tetracycline to macromolecules. Nature, Lond. 191: 1156-1158

Lambs, L., Brion, M., Berthon, G. (1984). Metal ion-tetracycline interactions in biological fluids. Part 3. Formation of mixed-metal ternary complexes of tetracycline, oxytetlacycilne, cuxycyciine and minocycline with caicium and magnesium, and their involvment in the bioavailability of these antibiotics in blood plasma. Agents Actions 14 743-750

Lambs, L., Venturini, M., Reverend, B. D. L., Kozlowski, H., Berthon, G. (1988). Metal ion-tetracycline interactions in biological fluids. Part 8 . Potentiometric and spectroscopic studies on the formation of $\mathrm{Ca}$ (II) and $\mathrm{Mg}$ (II) complexes with 4-dedimethylamino-tetracycline and 6-desoxy-6demethyl-tetracycline. J inorg. Biochem. 33: 193-210

Levy, S. B. (1984). Resistance to the tetracyclines. In: Bryan, L. E. (ed.). Antimicrobial drug resistance, Academic Press Orlando

Levy, S. B. (1988). Tetracycline resistance determinants are widespread. Am. Soc. Microbiol. News 54: 418-421

Neuvonen, P. J. (1976). Interactions with the absorption of tetracyclines. Drugs 11: 45-54

Oka, H., Ikai, Y., Kawamura, N., Yamada, M., Harada, K., Ito, S., Suzuki, M. (1989). Photodecomposition products of tetracycline in aqueous solution. J. agric. Fd Chem. 37: 226-231

Potts, W T. W., Parry, G. (1964). Osmotic and ionic regulation in animals. Pergamon Press, Oxford

Samuelsen, O., Torsvik, V., Hansen, P. K., Pittman, K., Ervik, A. (1988). Organic waste and antibiotics from aquaculture. Int. Counc. Explor. Sea Comm. Meet. (Maricult. Comm.) F: 14: $1-14$

Sparboe, O., Koren, C., Håstein, T., Poppe, T., Stenwig, H. (1986). The first isolation of Yersinia ruckeri from farmed Norwegian salmon. Bull. Eur. Ass. Fish. Pathol. 6(2): $41-42$

Usher, M. L., Talbot, C., Eddy, F. B. (1988). Drinking in atlantic salmon smolts transferred to seawater and the relationship between drinking and feeding. Aquaculture 73: $237-246$

White, J. R., Pearce, F. L. (1982). Characterization of chlorotetracycline (aureomycine) as a calcium ionophore Biochemistry, N.Y $21 \quad 6309-6312$

Manuscript first received: June 30,1989

Revised version accepted: May 31, 1990 